\title{
Relatório do Ministro Joaquim Henrique Coutinho
}

RELATÓRIO DO MINISTRJ JOAQUINi HENRIQUE COUTINHO, DO TRIBUNAL DE CONTAS DO RRASIL. SOBRE AS TESES DA $2^{\circ}$ COMISSÃO

A Itàlia propôs, perante a Secretaria do III Congresso Internacional das Instituiçõe: Superiores de Contrôle das Finanças Públicas, para constar da Agenda, o tema:

"Atribuições do Organismo Superior de Fiscalização, no que concerne às receitas".

Despartuu, desde logo, as atenções dos integrantes do Corpo Deliberativo do Tribunal de Contas da União, como Membros Natos que são do Congresso na fase atual, a relevância da tese proposta e, assim, de acôrdo com a Secretaria Permanente de Havana, foi ela escolhida para estudos e debates, passando e constituir a segunda parte da Agenda.

Ao Brasil, como participante de todos os Congressos anteriores e sede do atual, coube a honrosa incumbência de orientar os trabalhos na parte referente à divulgação das teses apresentadas e, após os debates, coletar dados e fixar opiniões para a conclusc̃o, que deverá representar o pensamento do Congresso.

Como Delegado do Brasil e Membro do Tribunal de Contas da União, quero agradecer a grande distinção concedida ao meu pais quando o conclave reúne as mais altas autoridades mundiais do Direito Financeiro e Fiscal, curvando-me reverente à decisão da Comissão Geral do Congresso, que me indicou para desempenhar o desvanecedor encargo de Relator-Geral do tema.

Assumindo tão grande responsabilidade, despenderei, por certo, os maiores esforços para o que o assunto desperte, em seus debates, o interêş̌ de todos os componentes dêste certame que vem empolgando os estudiosos do Direito Financeiro, os técnicos de contabilidade pública, os responsáve:s pela fiscalização financeira e, com muito maior razão, os intzgrantes das Côrtes die Contas.

Nu desempenho, pois, da tarefa que me foi cometida, tenho a declarar perante o Plenário que me foram entregues pela Secretaria do Congresso teses apresentadas pela Itália, Bélgica, Portugal, Suíça, Espanha, Austrália, Iugoslávia, Nova Zelândia, China e Japão.

Procurei, com a mais severa procupação, fazer uma sintese de cadā tese, ressaltandc: as opinióes e conceitos emitidos, a fim de que os tra- 
balhos pudessen: ter seu desenvolvimento mais acelerado sem prejuizo do entendimento necessário a uma conclusão acertada.

Os ilustres Congressistas hão de, por certo, perdoar o tempo que, ainda assim, lhes roubo com a extensão do meu relato, mas a relevância dos assuntos em debate e o interêsse que vem despertando o Congresso impõem que constem do mesmo, embora de um modo sintético, os motivos das propostas de cada país.

\section{II - SíNTESE DAS TESES E TRABALHos}

\section{Itália}

$\mathrm{Na}$ Itália, a realização das receitas ocorre através de um complexo processo administrativo - o sistema jurídico das receitas.

Nas normas sôbre a organização e funções do Tribunal de Contas da República Italiana está previsto que êle exerça "uma vigilância sôbre as receitas". Mas não existem, contudo, normas que explicitamente indiquem como e dentro de que limites se deva desenvolver êsse contrôle.

Atualmente, êle se concentra no exame das previsões rasumidas das receitas, que sãc enviadas periòdicamente pelas administrações, mas que não permitem um exame analitico das diferentes operações e da respectiva regularidade.

Providências de caráter ocasional auxiliam a fiscalização: relatórios e atas de verificação que, por lei, devem ser enviados ao Tribunal e se referem quer diretamente aos serviços de arrecadação das receitas, quer a regularidade das gestões dos funcionários e agentes; contrôle preventivo sôbre contrates que excedam determinada importância etc.

Também no terreno jurisdicional, seja através do exame das contas Judiciais, que são efetuadas em relação a todos quantos manipulem dinheiros públicos, seja mediante denúncia ao Procurador Geral junto ao Tribunal, por parte das repartiçôes de contrôle, pode ser efetuada a fiscalização.

O Tribunal tem podêres para solicitar aos Ministros, às administrações e ans funcionários que dêles dependam, as informações e os documentos que se refiram à arrecadação, à despesa e tôdas as notícias e documentos necessários ac exercício de suas atribuições.

Pode, ainda, determinar, por sua secão de contrôle, eventuais verifi cações direta: junto a funcionários e agentes que manipulem dinheiro ou materiais de propriedade do Estado.

Até 1917, existia, junto à Côrte de Contas, uma "divisão de receita especial" que apresentava, para cada capítulo do orçamento, suas próprias escritas analiticas, chamadas "livros mestres das receitas" e estava em condições, no fim do exercício, de confrontar suas próprias escritas com a do Ministério das Finanças - sistema que foi necessário abandonar por fôrça do desenvolvimento dos serviços públicos. 
Propõe: instituição de sistemas de escrituração e de verificação mais modernos c amplamente mecanizados, tanto nos ministérios quanto no órgão controlador das finanças públicas.

Seriam transcritos mecânicamente e com poucas unidades de trabalho os levantamentos analíticos referentes às receitas confrontando-se, no fim de cada exercício, os resultados do órgão de contrôle com os das contadorias.

Coordenar-se-iam, também, orgânicamente, os. diversos sistemas ocasionais de fiscalização atualmente usados, utilizando-se inspetores especiais de formação e preparação prévias, para procederem a verificações junto às administrações ou aos agentes encarregados da arrecadação da receita.

\section{Bélgica}

Há que considerar as diversas receitas que compõem seu orçamento: do Estado, das províncias; dos municipios; do Congo Belga e da Ruanda Lirundi, e, finalmente, dos organismos de interêsse público. A forma de arrecadação e o contrôle de cada uma dessas receitas obedecem a sistemas pátrios.

A Côrte de Contas - a quem a Constituição confia várias atribuições em matéria de fiscalização financeira e especialmente o encargo de controlar as contas da Administração Geral e de todos os exatores do Tesouro, submetendo o balanço anual do Estado, com suas observações, às Câmaras Legislativás, incumbidas de votar a lei orçamentária - pode, no cumprimento de suas atribuições, colhêr tôdas as informações e verificar quaisquer documentos contábeis.

I -- No que refere às Receitas do Estado, a lei orgânica de contabilidade - de 1846 - estabelece que os ministros remetam à Côrte de Contas um quadro pormenorizado dos bens e rendas do Estado; traslados das atas de leilão de cortes de madeiras, aluguéis de propriedades, vendas de objetos móveis e outros documentos análogos; extratos dos montantes dos irpostos diretos, com discriminação por provincia e municipio, e todos os demais documentos que comprovem as rendas do Estado.

As arrecadações só podem ser efetuadas por exatores responsáveis perante o Tribunal de Contas, a quem prestam contas anuais de sua gestão.

O contrôle exercido por êste - que não intervém na estimativa das receitas - é efetuado a posteriori, ao contrário do que ocorre em relação às despesas, de vez que, por fôrça das disposições legais, a remessa das contas de arrecadações só se efetua após o final da gestão anual.

Também sua função fiscalizadora só é pràticamente exercida pelo cotejo dos comprovantes enviados pelas repartições, de vez que nenhum texto legal o habilite a uma fiscalização in loco. 
As atribuições da Côrte de Contas abrangem três aspectos sucessivos que se entrelaçam e se completam: verificação das receitas arrecadadas pelos exatores; verificaçăo do depósito e da centralização das receitas no Tesouro e verificação da conta gera! do Estado.

Verificação das receitas arrecadadas pelos exatores - Em principio, a arrecadaçäo dos dinheiros públicos só pode ser efetuada por um exator do Tesouro e, assin, todo pagamento feitc e êste deve ser comprovado em uma conta de exator - a qual, obrigatòriamente remetida à Côrte até o dia 30 de abril de cada ano, deve abranger os atos da gestão, de $1^{\circ}$ de janeiro a 31 de dezembro, incluinóo especialmente os valores existentes em caixa e na carteira no início do exercicio; as importâncias a arrecadar, as receitas recebidas e as despesas realizadas, discriminadas por exercício, e impostos, bem como as importâncias em caixa e na carteira do exator e as somas ainda a arrecadar no final da gestão.

Verifrcação do depósito e da centralização das receitas no Tesouro Qualquer depósito efetuado, quer por coletor público quer por devedor do Estado, dá lugar a expedição de recibo liberatório em cujo talão se faz o histórico do pagamento.

Êsses depósitos são recebidos pelo Banco Nacional da Bélgica, na qualidade de caixa-geral do Estado ou por conta-corrente postal administrada pelo Ministério da Fazenda lencarregado de centralizar, na contabilidade geral, o montante de tôdas as entradas de fundos nos cofres publicos).

A Côrte de Contas fiscaliza tais operações, já que o Banco Nacional e o administrador da conta corrente postal representam o papel de exatores.

Uma de suas mais importantes atribuições nesse setor é o contrôle do produto dos empréstimos da Divida Pública, verificando se os mesmos foram contraídos pelo Estado mediante autorização legal e se estão de acôrdo com as condições de emissão preestabelecidas.

Verificação da conta getal do Estado - E' uma das atividades essen. ciais da Côrte de Contas. Essa conta, acompanhada dos comprovantes, é enviada àquela entidade no segundio trimestre do ano que se seguir ao da gestão, a qual deverá submetê-la ao Parlamento no mês de setembro seguinte, formulando as observaçóes que julgar convenientes, a fim de que êste fique habilitado a dar quitação ao govêrno.

A conta geral, bem como o Livro de Observações da Côrte de Contas, - documento da maior importância - são publicados por decisão da Câmara dos Deputados.

II - Quanto às receitas das provincias - cujos orçamentos são votados anualmentz pelos conselhos provinciais e submetidos a aprovação do Rei antes de sua execução -.. são fiscalizadas pela Côrte de Contas através das contas dr tesouraria geral e da conta orçamentária, enviadas até 15 de março de cada ano seguinte à gestăo. Também foi prevista pela lei provincial a existência de exatores responsáveis perante aquêle órgão de con- 
trôle, sendo aplicáveis às províncias as regras estabelecidas para a prestação de contas dos fundos to Estado, e conferida à Côrte de Contas poder jurisdicional no tocante aos exatores provinciais.

O contrôle abrange a centralização das receitas, efetuada por um exator provincial, e a conta orçamentária anual, rematendo a Côrte suas eventuais observações ao governador da província, antes da sanção definitiva pelo Conselho Provincial.

III -- No que tange às receitas dos municípios, a Côrte de Contas não tem atribuições legais para seu contrôle - exercido pela Comissão Permanente do Conselho Provincial.

IV - Na parte das receitas do Congo Belga e de Ruanda Urundi, cuja conta anual é sancionada por lei depois da verificação pela Côrte de Contas, a fiscalização apresenta os mesmos aspectos daquela das receitas do Estado, apenas não tendo a Côrte poder jurisdicional com referência aos exatores.

A conta geral - nas mesmas condições que a do Estado - é publicada por decisão da Câmara dos Deputados, com as observações da Côrte de Contas.

Finalmente, no quz diz respeito às receitas dos organismos de interêsse público, verifica-se que êstes estão divididos em quatro categorias, sendo sòmente duas controladas pela Côrte de Contas e que são: a) administração com personalidade (autarquias etc.), em que o contrôle se exerce através das contas de execução de orçamento e, ainda, por verificações in loco, sendo que as conclusões da Côrte, juntamente com a conta anual da gestão, figuram no livro de observações que ela apresenta ao Parlamento: $b$ ) estabelecimentos públicos cujos recursos provêm de subvenções do Estado e cotizações ou contribuições obrigatórias, cujas contas são submetidas à Côrte de contrôle, que as verifica, as mais das vêzes, in loco.

Êsses orçamentos não sãı stubmetidos ao Parlamento, embora as contas de gestão figurem no Jivro dc Observações enviado àquele.

As outras duas categorias - órgãos nos quais o Estado está associado com interêsses públicos ou privados e instituições de depósito de crédito ou de aval de crédito - têm seus orçamentos amplamente enviados ao Ministro da Tutela e Minıstro da Fazenda. Entretanto, nos Estatutos de alguns dêles está prevista a prestação de contas ao Tribunal. As contas dêste figuram no Livro de Observações destinado a informar o Parlamento.

\section{Frariça}

Desde as mais remotas origens. o organismo superior de fiscalização sempre foi investido, na França, de uma missão de contrôle das receitas públicas, embora, no curso de uma longa história que se estende da Idade Média aos nosso dias, a natureza e o entendimento dêsse contrôle se hajam notàvelmente modificado. 
Sempre considerado como uma tarefa essencial de alta jurisdição, o exame das receitas se adaptou à evolução dos recursos públicos após vários séculos. O Tesouro público, outrora alimentado principalmente pelos produtos do domínio, apela, nos tempos modernos, cada vez mais para os impostos. O montante dessas contribuições fiscais foi crescendo com o desenvolvimento do intervencionismo do Estado, atingindo, agora, cêrca de $2 / 3$ das despesas totais do orçamento. Quanto às coletividades locais, seus recursos são constituídos pelos impostos e pelas subvenções recebidas do Estado.

O contrôle dessa enorme massa que representam as receitas orçamentárias não podem incumbir ùnicamente a um organismo superior de contrôle. Uma divisão de competência ao comêço inútil tornou-se depois indispen sável.

A percepção dos impostos notadamente levantou um grande número de contestações devido à adversidade dos casos individuais. Um certo número dessas contestações pode ser resolvido pela administração. Mas outras, bastante numerosas, devem ser deferidas aos tribunais, em razão não só do desejo dos contribuintes de defender melhor seus interêsses, como das dificuldades de interpretação das numerosas leis fiscais. O julgamento dêsses litígios foi confiado aos tribunais judiciários ou administrativos de direito comum. A parte da Côrte de Contas se tornou, portanto, na França, limitada, salvo exceção, ao contróle das operações de receitas efetuadas pelos exatores públicos - o que representa já uma imensa missão.

O regime adotado estabeleceu a seguinte divisão de competência:

- Os tribunais judiciários e administrativos julgam o conteúdo legal, isto é, pronunciam-se sôbre os litigios que lhes são levados pelos contribuintes ou pela administração.

- A Côrte de Contas controla a legalidade das receitas públicas por ocasião do julgamento das contas das coletividades públicas cuja competência lhe foi atribuída; por seu comitê de taxas vela particularmente pela legalidade das taxas municipais. Mas não se pronuncia jamais sôbre as questões individuais entre os contribuintes e os serviços administrativos.

Em virtude do art. 20 da Lei de 16 de setembro de 1907, os relatores devem mencionar em seus relatórios as observações "que possam resultar da comparaçãı da natureza das receitas com as leis". Esse texto prevê portanto um contrôle geral da Côrte sôbre a legalidade de todas as receitas, notadamente das taxas e impostos recebidos pelas diversas coletividades públicas da sua alçada.

O contrôle a posteriori apresenta com efeito o grave inconveniente de intervir muito tarde, em uma época em que a taxa ilegal pode já haver sido recebida um ou vários anos c os reembolsos aos contribuintes ilegalmente obrigados atinjam um montante elevado e de natureza a comprometer o equilibrio de orçamento municipal.

Por isso o decreto-lei de 30 de outubro de 1935 estabeleceu que os exatores devem transmitir no prazo de um mês, à Côrte, os atos contendo 
modificação ou criação de taxas para as comunas sujeitas à jurisdição daquela Côrte, e que esta deve formular àqueles suas observações no prazo de 3 meses. Sempre que uma taxa é deciarada ilegal pela Côrte e que uma nova deliberação da autoridade municipal decide por sua manutenção, uma ação é intentada a fim de cbter a anulação dessa receita.

O poder de decisão sôbre a legalidade das taxas foi, depois de 1941 confiado a um organismo especial, a Comissão Tributária, cujos membros e relatores são magistrados da Côrte. O processo de anulação, da competência desta é utilizado nas questões mais difíceis.

O contròle a posteriort da Còrte de Contas sôbre o recebimento das receitas é duplo: jurisdicional e administrativo. Èsses dois contrôles têm um caráter comum, a generalidade. mas diferem notàvelmente quanto a seu conteúcio e sula sanição.

O contrôle jurisdicional resulta das leis que instituiram a Côrte, em $180 \%$, e que determinam que ela fiscaliza e apura as contas que lhe são apresentadás pelos responsáveis por dinheiros públicos em receita e despesa, e enumeram os que àquela época estavam sob sua jurisdição : contas de receitas do Tesouro, dos recebedores gerais do departamento e da administração das contribuições indiretas. Mas essa enumeração não tem caráter limitativo. A Côrte é juiz de direío comum, o que quer dizer que ela julga todos os responsáveis por dinheiro públicos, salvo as exceções feitas pela legislador. Essas cxceções sảo extremamente raras.

Por outr : lado, a competência da Côrte quanto aos "gestores de fato" permite a essa alta jurisdição pronunciar-se sôbre as receitas públicas recebidas por outras pessoas que não os exatores.

O contrôle jurisdicional exercido pela Côrte de Contas na arrecadação do total das receitas ć um contröle da regularidade.

O alcance dêsse contrôle da regularidade é determinado segundo o princípio geral de que a Côrte nã̃o pode exercer sua competência jurisdicional sem que a responsabilidade de um exator esteja envolvida.

Assim, êsse contrôle é limitado, quanto às receitas, às operações efetuadas pelos responsáveis. As operaçñes relativas ao lançamento das receitas são da competência do administrador.

O contrôle administrativo a posteriori tem um caráter muito geral: êle é relativo as conjunto das receitas que figuram nas contas sujeitas ao exame. É, assim, uma extensc̃o muito grande que permite à Côrte verificar. entre as condiçũes do recebimento das receitas pelos exatores, as operações da competência dos administradores. como determinação da escrituração, fixação dos direitos a receber, emissão de títulos, etc.

O contrôle administrativo resulta dos textos constitucionais. $\mathrm{O}$ artigo 47 da Constituição de 5 de cutubro de 1958 indica que "A Côrte de Contâs assiste o Parlamento e o Govêrno no contrôle da execução das leis finanças",

A organização do contrôle das receitas varia com a evolução dos recursos públicos. Menos inquisidor em geral para os recursos tradicio- 
nais ou permanentes, o contróle torna-se mais vigilante para os provenientes de receitas recentemente criacos cu de caráter ocasional.

Por outro lado, o contrôle de uma massa tão importante como a das receitas públicas exige métodos mais flexíveis e mais rápidos que outrora. Para assegurar condições de recebimento, vigilância dos atrasos e o cancelamento de parcelas não cobráveis, os contrôles in loco são freqüentemente indispensáveis .

Enfinı, as observações mais importantes em matéria de receitas não são apenas objeto de comunicaçôes ao govêrno e ao Parlamento. São também freqüentemente incluidas no noticiário público. É indispensável que a opiniăo públic: seja informada das irregularidades e das anomalias que se possam produzir no recebimento das receitas. Numa época em que a importância das contrihuições públicas se tornou considerável, o contrôle da Côrt: de Contas deve constituir pará todos a garantia de que os serviços encarregados do recebimento das receitas cumprem sua missão respeitando permanentemente a regularidade da arrecadação e com o cuidado constante da eficácia administrativa.

\section{Portugal}

Em Portugal, muito embora o organismo superior de fiscalização das receitas públicas seja o Tribunal de Contas, que julga, a posteriori, as contas dos responsáveis, sutros órgãos do Estado também são encarregados, em determinados setores, dessa fiscalização.

O Banco de Portugal funciona como Caixa Geral do Tesouro na metrópole, enquanto no ultramar c sistema de tesouraria inclui os Bancos Nacional Ultramarino e o de Angola.

As tesourarias da Fazenda Pública do Ministério das Finanças, coad. juvam o Banco de Portugal em suas funções de caixa-geral do Estado, exigindo se dos tesoureiros caução cujo valor é arbitrado conforme a categoria do conselino onde desempenham as suas funções.

Quem organiza a conta de responsabilidade dos tesoureiros a ser sub. metida ao Tribunal de Contas é o chefe da Seção de Finanças, da Direção Geral das Contribuições e Impostos, que exerce funções idênticas às de guarda-livros.

No ultramar, só as contas dos tesoureiros gerais dos dois bancos que funcionam como caixa-geral do Estado é que são julgadas naquela alta instância fiscalizadora, pois os tribunais administrativos ultramarinos (que funcionam como tribunais de contas) têm a atribuição de julgar tôdas as outras contas de responsabilidade dos exatores.

O movimento relativo às receitas das provincias ultramarinas está, entretanto, incluido nas contas gerais que, segundo determina a Constituição, são anualmente submetidas a julgamento pelo Tribunal de Contas. 
O Tribunal de Contas verifica, além da fiscalização exərcida sôbre os responsáveis pela guaría de bens e valores públicos, ainda:

a) a exatidão das receitas previstas (por intermédio do orçamento garal do Estado e pelo seu fichário, que contém as alterações por que passararil as verbas inscritas na previsão orçamentária);

b) as receitas liquidadas, cobradas, anuladas ou em divida (pelas demonstrações modêlo 30 e tabelas de rendimento, cujo movimento não está incluido naqualas que săs remetidas pelos restantes cofres públicos);

c) o movimenti do erário público, extraordinário (por meio de tabelas de entrada e saidá de fundos modêlo 29).

Com base na apuração geral das receitas - segundo as contas de todos os exatores ... o Tribunal organiza mapas que devem ser confrontados com os dados constantes cios documentos acima referidos.

Compete à repartiçáo fiscalizadora da Conta Geral do Estado do Tribunal de Contas apurar os erros e promover as retificações necessárias, caso surjan divergências.

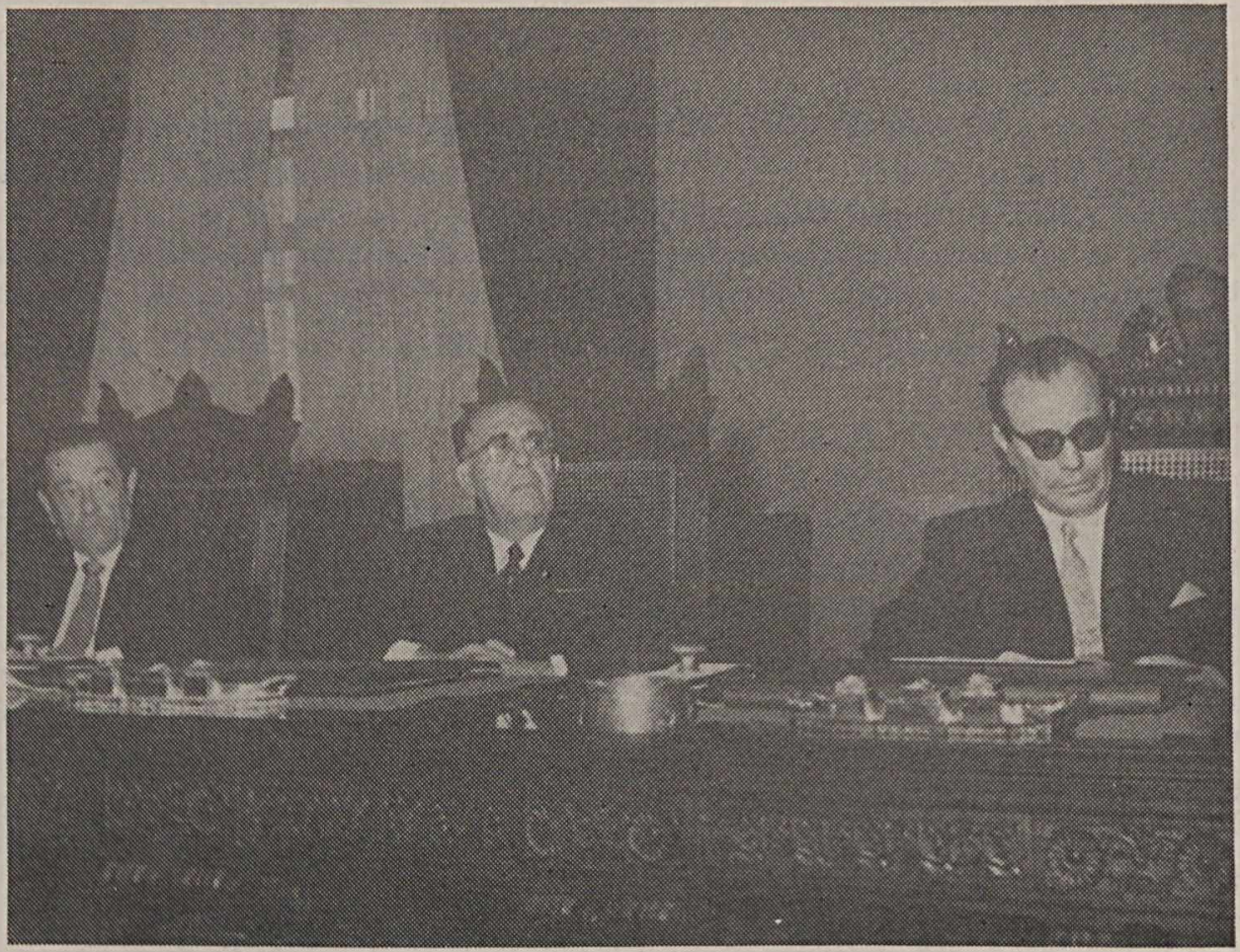

LIma das Sessões onde se vêem o Secretário do III Congresso Mundial de Tribunais de Contas - Ministro Rogério de Freitas; o Ministro Henrique Coutinho, ao centro, que apresentou relatório sôbre as teses "Atribuiçóes do Organismo Superior de Fiscalização no que concerne às receitas"; e ainda o chefe da Delegação de 


\section{Suiç̧a}

Na Suíça, o Contrôle Federal das Finanças é o órgão superior de fiscalização financeira da Confederaçâo, sendo de notar que, devido à organização federalista, os cantões e municipios possuem suas próprias instituições de contrôle. Êle faz a tevisăo permanente de tôdas as contas, documentos contábzis e registros de inventários.

A organização contábil da Confederação Suíça oferece ao órgão superior de contrôle a possibilidade de ser exatamente informado da situação e da evolução das receitas e das despesas.

No que se refere às receitas, as administrações encarregadas de sua arrecadação devem contabilizá-las palo lançamento de uma conta de capital que é aberta pela Contabilidade Central, creditando-as sob os titulos orçamentários das receitas correspondentes.

Os devedores do Estado se eximem de suas obrigações por meio de pagamentos efetuados na Repartição de Cheques e Guias Postais, no Banco Nacional Suiço ou na Caixa do Estado que creditam êsses pagamentos na Contabilidade Central.

Os contrôles relativos às receitas ocorrem principalmente a posteriori, por ocasião das inspeções periódicas nas várias repartições administrativas, quando o Contrôle Federal das. Finanças constata, por meio de sondagens, regularidade das receitas arrecadadas.

\section{Espanha}

As receitas são arrecadadas pelo Ministério da Fazenda, Diretor-Geral do Tesouro, Dividas e Aposentados; Delegacias e Subdelegacias da Fazen da: Tesourarias da Fazenda; Recebedorias-Pagadorias; Inspetores das zonas arrecadadoras e pessoal arrecadador.

O Tribunal de Contas, na Espanha, efetua a fiscalização das firanças públicas a posteriori, não exercendo assim, uma vigilância e um contrôle imediatos sôbre o proceissu arrecadador. Êsses são exercidos por um outro órgão fiscalizador, clependente da administração ativa, e que é a Interventoria Geral da Administração do Estado.

O Tribunal de Contas não fica, entretanto, totalmente afastado da vigilância do serviço arrecadador, de vez que a efetua através do processo de tomada de contas - ordenando a seus Delegados Instrutores medidas baseadas nas normas do processo arrecadador e de seus meios para efetuá-lo; através da execução de suas sentenças, que são comunicadas ao Delegado Instrutor, que, para cumpri-las. recorre àquelas normas; na fiscalização imediata das receitas do pessoal arrecadador, as quais são incluídas as contas da Tesouraria, e nos casos de alcance, quando intervém no processo determinando o embarço da fiança a sua aplicação na cobertura de débito. PROFÕE:

$\left.1^{\circ}\right)$ as atribuições do órgão superior de contrôle serão maiores ou menor'es. segundo a fiscalização que exerçam - a priori e a posteriori conjuntamente, ou simplesmente a última; 
2\%) como função preventiva cabər-lhe-á principalmente a vigilância dos órgãos diretament? encarregados $\mathrm{d} z$ arrecadação, no que diga respeito à designação di zorias arrecadadoras, nomeação do pessoal arrecadador, prestação de fianças, vigilância dos trâmites do processo arrecadador e execução de sentenças.

3) como função consultiva, caber-lhe-á o julgamento final das contas apresentadas pelo pessoal arrecadador, ação para ressarcir o Estado dos prejuizos ocasionais pela administração arrecadadora, realizar embargos e exigência de prestação de contas;

\section{Austrália}

A Constituiçã.) australiana determina que tôdas as quantias arrecadadas ou recebidas pelo Poder Execurivo sejam recolhidas ao Fundo Consolidado da Receita.

A maior parte da receita é obtida pela arrecadação de tributos, direitos aduaneiros, impôsto de consumo e serviços postais.

Os métodos de previsão da receita a ser arrecadada e seu subseqüente registro variam para cada tipo de receita. Um princípio geral observado, entretanto, na organização de todos os Departamentos em que seja arrecadada qualquer parcela apreciável da receita é o da completa separação das funções de: prever ou determinar c montante a ser arrecadado; registro dos montantes previstos, arrecadados e pendentes; recebimento e contabilização dos dinheiros.

Hâ uma Lei de Contrôle das Contas que determina que todo funcionário contábil deve. em intervalos fixos, encaminhar ao titular do Tesouro ou ao substitutı dêste uma relação das quantias recebidas, indicando o montante de cada rubrica da receita.

Também c Contador Interno de cada repartição fornece à Administração relatórios acessiveis acs Inspetores do Auditor-Geral.

O Auditor-Geral - nomeado pelo Governador-Geral ex-vi da Lei de Contrôle de Contas - responsável apenas perante o Parlamento, examina a conta do recebimento da receita bem como as contas de cada recebedor de dinheiros públicos legalmente pagáveis ao Estado, podendo exigir que qualquer pessoa compare $: \nexists$. Auditoria para prestar esclarecimentos, estando mesmo autorizado por lei a inquirir pessoas sob juramento, declaração ou afirmação.

A Lei de Contrôle de Contas determina que o titular do Tesouro prepare, após o encerramento de cada exercício e tão pronto seja possível, um Relatório Financeiro discriminando as transações do Fundo Consolidado da Receita, do Fundo de Empréstimos e do Fundo Fiduciário, encaminhando-o ao Auditor-Geral, o qual deverá enviar, após, relatório ao Parla- 
mento sôbre o assunto, esclarecendo os casos de falta de arrecadação ou contabilização de qualquer quantia, e todos os casos de responsabilidade não resolvidos.

Esse relatório entra na ordem do dia do Parlamento logo após a apresentação do Orçamento, a fim de ficar à disposição dos seus membros durante o debate sôbre as previsöes.

\section{Japão}

Há cêrca de 40 contas especiais, estabelecidas em lei, para que o govêrno possa cunhecer exatamente a situação de cada fundo público.

As corpoụações públicas, como a Estrada de Ferro Nacional, são obrigadas a apresentar à Dieta o orçamento de sua receita e despesas, de acôrdo com a lei.

A Auditoria tem, como a mais importante de suas funções, a prevista na Constituição (art. 90) : a fiscalização do encerramento das contas de receita e despesa do Estado.

A fiscalização da criação e liquidação dos créditos do Estado é, em regra, feita em conexão com a das receitas, embora às vêzes haja uma fis calizaçã̃) separada sôbre a própria preservação dos créditos.

$\mathrm{Na}$ fiscalização da receita de impostos, que é a parte principal da conta geral de receita, são examinados os seguintes aspectos: se o montante dos impostos está de acôrdo com a legislação; se foram ou não usados para os fins determinados em lei; se houve excesso ou deficiência no recolhimento.

Se houver excess') ou deficiência, a Auditoria imediatamente comunica o fato ao Ministério diss Finanças para correção da irregularidade.

Procedimento semelhante deve ter a Auditoria em relação às taxas de seguro estadual, como o seguro-desemprêgo.

No que se refere aos contratos com pessoas ou entidades não oficiais, como por exemplo para alienação de próprios nacionais, são êles conduzidos pela Auditoria, desde a sua origem até a conclusão. Tal procedimento tem por objetivo verificar se o contrato foi concluído não exatamente, de acôrdo com os regulamentos; se o preço estimado pelo govêrno foi apropriado, ou se foi muito baixo.

O exam? da superintendència e dos créditos, desde o seu surgimento até o final, envolve as seguintes verificações: se os juros foram corretamente arrecadados ou não; se os prazos para o pagamento das taxas de empréstimos de ex€cução compulsória são razoáveis.

O Banco do Japão é o caixa-geral do Estado e tôdas as receitas do país a êle devem ser, obrigatòriamente, recolhidas. 


\section{China}

Recunhecendo a tributaçãc como a principal fonte de renda do govêrno e o problema mais importante aquèlc de enriquecer os cofres públicos mantendo baixos os impostos, Propõe, para alcançar a harmonização dêsses interêsses:

$\left.1^{\circ}\right)$ que se atribua igual importância à receita e à despesa pública;

$2^{\circ}$ ) que os tribunais de cointas recomendem seja mantida a receita dentro da capacidade tributária do povo;

3:) que cs auditores sejam acreditados junto ao Tesouro Nacional a fim de verificarom os depósitos e retiradas efetuados na Conta Geral do Depósitos do Govêrno e, ainda, incumbidos da supervisão de tôdas as agências arrecadadoras (ou, pelo menos, de visitá-las ocasionalmente);

4:) que o sistema de lançamento seja distinto do de arrecadação;

5) que o: beins públicos sejam vendidos através de concorrências, supervisionadas por auditores para êsse fim designados;

6:) que os tribunais de contas possam sugerir os melhoramentos e emendas às verbas orçamentárias destinadas ao custeio dos exames de contas, se tais melhoramentos ou emendas forem capazes de promover a eficiência econômica e eliminar gastos desnecessários.

\section{iugoslávia}

As receitas do Estado na RPH da Iugoslávia compreendem não só as constituintes de Orçamento Federal como as das demais entidades politicoterritoriais (Repúblicas federadas, entidades autônomas, distritos e municipios) que tîm orçamentos autônomos, as das instituições com financiamentu próprio e as dos fundos orçamentários \& sociais.

As entidades politico-territoriais executam certos serviços públicos (hospitais, teatros, museus, etc.), através de instituições de financiamento próprio, mas cujos orçamentos são anexados ao da entidade político-ter ritorial cujos órgãos as tenham instituído. As receitas de tais instituições, se apresentarem superavit, têm êste transferido ao orçamento da entidade politico-territorial correspondente. E se, ao contrário, as despesas forem superiores à previsão da receita, o excedente será coberto com os recursos da entidade-territorial.

Também tem caráter análogo a receita das associações obrigatórias das entidades econômicas, de modo que a comunidade não pode desinteressar da sua formação e emprêgo.

Tôda uma série de necessidades públicas é atendida através de fundos públicos especiais (de seguro social de estradas e caminhos, de agricultura, de atividades editoriais etc.). Cada um dêsses fundos tem seu próprio orçamento de receita e despesa. 
Assim, quando se consideram as funções das Instituições controladoras das receitas estatais, há que levar $\mathrm{em}$ conta aquelas circunstâncias, pelo que caberia melhor o têrmo receitás públicas ou receitas sociais do que receitas estatais.

Segundo suas fontes, as receitas públicas podem sa dividir em três grupos principais:

a) receitas provenientes da população;

b) receitas provenientes das entidades econômicas; zações.

c) receitas das instituições, de órgãos estatais e de outras organi-

As primeiras sáo constituídas pelo impôsto sôbre a renda, pelos tributos, impostos sôbre sucessões, doações e taxas.

As segundaj compôem a maior parte das receitas dos orçamentos e se distinguem das receitas semelhantes em outros paises porque, sendo as emprêsas de propriedacle nacional, assumem o caráter de contribuição à comunidade parä satisfação das necessidades públicas.

As Diretorias da Receita velam pela realização das receitas prove. nientes da população (impôsto sôbre a renda, encargos locais, etc.), pois são elas próprias, de acôrdo com as disposições legais, que distribuem os tributos e efetuam a arrecadação e a contabilidade de tais receitas ocupando-se menos com as provenientes das entidades econômicas e dos óryãos estatais e instituições.

Em matéria de receita, o setor mais importante é o das entidades econômicas, porrutue nêle se tealiza a imensa maioria das receitas dos orçamentos e fundics -.. do que resulta se dedicar especial atenção ao funcio namento correto das estimativas $c$ das arrecadações nessas entidades.

Além dos órgãos administrativos já mencionados e dos bancos encarragados de zelar pela realização das receitas dos orçamentos e dos fundos, existe também um órgão especial, encarregado de exercer inspeção direta sôbre a aplicaçã̃o de tôdas as normas financeiras. Este órgão especial, a Inspetoria Financeira, teria a seu cargo tamberm a inspeção das atividades das pessoas físicas e juridicas que se ocupam de atividades econômicas indepencientes - mas sòmente no que diz respeito à aplicação das normas que regulam suas obrigaçõrs financeiras para com a comunidade.

A Inspetoria Financeira exerce suas funções por meio de Inspetores Financeiros, que se distinguem dos demais funcionários da administração estatal por exercerem com plena autonomia a inspeção direta das atividades das entidades e cios orgãos, determinando correções de faltas, fixando prazos para tanto e devencio, por isso, ser bons conhecedores da legislaçã̃ financeira e peritos em contabilidade.

Os órgãos que inspecionam as atividades da Inspetoria Financeira poden ditar-lhes linhas diretrizes para seu trabalho ou encarrzgá-la de tarefas concretas, mas sem fixar a forma como as cumprirá nem o que 
há de ordenar em suas decisões - c que dá idéia da amplitude da autoridade dos inspetores financeiros.

Atualmente está sencio examinada a possibilidade de uma vinculação mais estreita entre o serviço de investigação social dos bancos e a inspeção financeira, para torná-los mais eficazes e independentes do que o têm sido até hoje.

\section{Nova Zelândia}

O Departamento de Contas, criado pela Lei de Receitas Públicas de 1953, é quem controla as finanças do Estado.

No que se refere à receita, verifica. se as regras e processos aplicados para sua classificação, lançamento $€$ arrecadação são adequados. Pode obrigar o responsável pur qualquer arrecadação a pagar o que, por negligência, não arrecadou.

Em seu relatório anual ao Parlamento, embora não tenha especificamente essa atribuição, menciona as variações importantes que hajam ocorrido em relação às previsões orçamentárias.

Além de examinar as cuntas públicas, o Departamento verifica as contas de mais de 2.000 autoridades locais e organizações fiscalizadas pelo Govêrno.

\section{Turquia}

Conforme o art. 100 da Lei Constitucional da Turquia, o seu Tribunal de Contas, ligado ao Parlamento, tem o direito de controlar as despesas e rendimentos do Estado.

São de duas categorias as funções e atribuições daquela entidade: acadêmicas, controlando. incessantemente, o sistema de contas do Estado e submetenito, por meio de un: relatório, à Grande Assembléia Nacional, as propostas de modificações e melhoramentos que julgar necessários; e relativamente à aplicação da Lei de Contabilidade do Estado, controlando os levantamentos de contas, a arrecadação e as operações anuais dos cobradores.

Submete ao Parlamento, juntamente com a declaração de aprovação geral que ś obrigado a apresentar em relação ao orçamento, o resultado anual do contrôle referente à aplicação dos rendimentos do Estado função para que está devidamente equipado.

\section{Tailândia}

A maior parte das rendas nacionais é arrecadada por três Departamentos do Tesouro, a saher:

Departamento da Receita

Departamen:o do Impôsto de Consumo

Departamento da Alfândega 
Há 3 órgãus independentes que são responsáveis palo contrôle das finanças governamentais locais, sendo quue dois atuam como órgãos de con trôle prévio, em niveis diversos, enquanto que o terceiro funciona como entidade de exame a posteriori. O primeiro consta de pelo menos 3 funcionários nomeados, pelo Prefeito da cidade, que examinam os recebimentos e pagamentos da localidade. O segundo consta de uma comissão composta de 3 funcionários do Govêrno nacional e que procedem, mensal e conjuntamente, a um exame de tôda a receita e despesa e cujo relatório é apresentado ao Ministério do Interior.

O terceiro funciona como Fiscal Financeiro das Autoridades Governamentais locais en: todc o reino e se compõe de funcionários designados pelo Conselho de Contrôle Financeiro, procede o exame a posteriori de tôda a receita e despesa locais.

O exame das conzas de todos os órgãos governamentais da Tailândi compete ao Conselho de Contrôle Financeiro, a quem é atribuido:

- o exame do orçamento de receita e despesa do Reino, que é preparado anualmente pelo Tesouro e submetido à apreciação do Conselho de Ministros;

- o exame dos relatóros financeiros da Reserva Monetária Nacional;

- o exame das contas de todos os órgãos governamentais, inclusive os das rzpartições locais, regionais, provinciais e distritais.

Por fôrça da Lei do Conselho de Contrôle Financeiro, êste tem de, no desempenho de suas atribuições, fazer um exame completo dos balanços firanceiros anuais da receita e despesa do Reino, juntamente com o relatório dos negócios financeiros. Os balınços financeiros, depois de devidamente examinados e visados pelo Conseiho, são submetidos à Assembléia Legislativa.

Também pela mesn'a lei cabe-lhe proceder a um exame minucioso dus Relatórios Financeiros da Reserva Monetária Nacional, visando-os afinal, ben como dar um parecer sôbre se todos os recebimentos e pagamentos foram feitos em obediência aos requisitos legais.

Tôdas as organizações de propriedades do govêrno têm, também, suas contas submetidas a um exame completo pelo Consalho, que emite parecer a respeito.

A Lei de Distritos Urbanos e a Lei Municipal deram podêres ao FiscalFinanceiro das Autoridades Governarnentais Locais para proceder a um exame de tôda a receita e despesas das referidas autoridades, inclusive das emprêsas oficiais para exploração de serviços públicos e de outros empreendimentos estatais.

Quanto ao contrôle financeiro das autoridades governamentais locais, instituiu o Conselho um sisfema de contrôle prévio para as entidades metropolitanas de maior vulto. 
Como os governos locais da Tailândia adotam um sistema de contabi. lidade de tipo comercial, em que se registram despesas antes de serem realmente feitas as receitas antes de sua efetiva arrecadação, os relatórios fínanceiros contêm débitos e saldos a receber, todos sujeitos a um exame minucios? ${ }^{\prime}$ do Fiscal Financeiro das Autoridades Governamentais Locais.

O Conselho tem competência para exigir que os funcionários responsáveis por qualquer irregularidade reponham quaisquer quantias cuja prestação de contas não seja satisfatória.

\section{Brasi:}

\section{(Colaboração do Dr. Vitor do Amaral Freire)}

Considerando que é por meio de arredacação que os governos lavan a cabo sua politica econômicc-financeira, sobretudo estimulando a produção de bens de consumo e redistribuindo as riquezas e, ainda, que o critério tradicional de fixarem-se primeiro as despesas para depois buscarem-se os recursus necessários está évoluindo para um critério mais prudente, qual seja o de condicionar as despessas à capacidade tributária do povo; considerando que são responsáveis por malversação tanto os que desviam dinheiros ou valores públicos, quanto aquéles que contribuem para seu não recebimento, propõe:

1) - As instituições de contrôle, respeitadas suas atribuições, devam exercer a mais ampla fiscalizaçc̃o das: arrecadações.

$2^{\circ}$ - No exercício dêsse contrôle deve ser exigido do Poder Público integral obediência ans principios de unidade e de universalidade orçamentária, sendo que, quanto às receitas dos organismos autônomos, nada impede que se respeitem essas regras mediante demonstração das arrecadações dêsses. organismos, em capítulo isolado e anexo ao balanço anual do exercício financeiro.

3? - As instituições de contrôle devem ter competência para opinar prèviamente sôlre a proposta óçamentária e suas modificações, e sôbre todo e qualquer projeto cie lei que crie ou altere tributos, entendido êste têrno no seu mais aito sentido, c de maneira a abranger tôdas as espécies de arrecadações, quer as da Admististração direta, quer as dos órgãos autônomos.

$4^{\circ}$ - As instituições de contrôle devem exigir contas dos responsáveis pela Receita, de maneira a alcançar não só os que tenham recebido arrecadações como também aquêles que, por emissão, negligência, desídia ou má fé, possam contribuir para o não recebimento de dinheiros ou valores. públicos.

$5^{\circ}$ - $A_{3}$ instituições de contrôle devem exercer drástica fiscalização das operações de antecipação cia receita e exigir a liquidação obrigatória das masmas com os recursos arrecadados no respectivo exercício. 


\section{Austria}

Na Áustria, que é un Estado Federal, o contrôle de seu Tribunal de Contas abrange todos os atos financeiramente importantes praticados pelo Bund (govêrno central), Felas provincias federais (Bundeslander), pelas municipalidades, pelas instituições de seguro social e por todos os fundos e instituições independentes que seiam administrados por órgãos do govêrno central, das provincias federais e das municipalidades ou por ordem dêstes.

Além disso, sua fiscalização se estende a tôda a administração de emprêsas comerciais e indıstriais possuídas pelo govêrno federal, pelas provincias federais ou por uria municipalidade e às emprêsas financeiramente mantidas por uma dessas entidades.

O Tribunal, entretanto, pode apenas formular críticas sôbre as receitas e despesas. Caso as entidades nîio atendam a tais críticas e instituições terá que deixar à Assembléii Na Nonal e Dietas a correção das situações.

A lei determina, ainda, que constitui obrigação expressa do Tribunal de Contās verificar se as receitas podem ser aumentadas ou se podem ser criadas noves.

Em face de sua experiéncıa de cêrca de 200 anos, aquela Instituição ì de opinião que as côrtes cie cuntas devem ser encarregadas do contrôle das receitas - agindo como "procurator fisci" salvaguardando os interêsses do Estado, das municipalidades e de outras entidades públicas.

COMENT'ÁRICS SÔBRE O TEMA

Procurei, tanto quanto possivel, fixar, nas sinteses das teses, os seus pontos vitais.

A Itália, em propondo, com grande descortíno, solução para assunto de tão alta relevância, como o contrôle das receitas, não se limitou, conforme se depreende d. brilhante estudo apresentado, ao problema do seu recolhimento mas, independenteinente dessa fase final, que é também objeto da at:nçã) dos órgãos fiscais, prouurou avançar com a fiscalização até que a mesma enfrentasse a escorreita cobrança do tributo, sem qualquer deturpaçãs.

$\Lambda$ fiscalização da despesa tem sido, até hoje, o alvo do maior interêsse dos institutos de fiscalização financeira, variando os métodos de contrôle conforme os regimes vigentes em cada nação.

Sustentei perante o Tribunal de Contas da União, permitam-me a digressão, como um dos seus pares, quando proferi parecer sôbre as contas do Govêrno, que o registro prévio é o caminho mais seguro a uma perfeita fiscalização da despesa e aquêle que mais e melhor firma a ação da Côrte na fase fiscal.

Os vultos notáveis do Segundo Império, em nosso país, como homens experimentados e ciosos de una eficiente fiscalização da despesa, jamais 
tiveram outro pensamento, bastando citar as memoráveis palavras do Conde de Baependi, proferidas em Parlamento, quando se pretendia, em projeto, criar o Tribunal de Contas, afirmando:

"Se o Tribunal cie Contas que se pretende estabelecer se convertesse em tribunal de fiscalização das despesas públicas antes de serem feitas em tôdas e quaisquer repartições, poder-se-ia dêle colhêr proveito..."

Rui BARBosa, genial como era, quando cogitou, já no período republicano, da criação de mesmo Tíribunal de Contas, deixou gravada, em mensagera de sua autoria à Assembléia Constituinte, a lapidar sentença:

"Se não pudermos chegar a uma vida orçamentária perfeitamente equilibrada, não nos será dado presumir que hajamos reconstituído a prática e organizado o futuro".

$\mathrm{E}$, a par de outras consideraçôes, quanto aos fundamentos invocados para a projetada reforma, dizia:

"Só assim o orçàmerito, passa1ido, em sua execução, por êsse cadinho, tornar-se-ia verdadeiramente essa verdade, de que se fala entre nós, em vão, desde que nesse país se inauguraram assembléias parlamentares".

Essa foi sempre a orientação dos homens do Brasil, quando tiveram de enfrentar o problema da fiscalização da despesa, a fim de ser verificado o ato antes de ser executado, adotando-se assim medidas preventivas, ao invés de punitivas após a sua consumação.

Todavia, acontecimentos posteriores, cujos detalhes, não interessam à tese em estudo, levaram a aceitação do registro a posteriori os créditos distribuidos para conseqüente tomada de contas.

Mas, voltemos ao tema.

As Cartas Constitucionais, en criando as Côrtes de Contas, seripre se referem à fiscalização financeira. evidenciando, assim, que ela constitui um todo, que tanto os atos da despesa quanto os de receita estão jurisciicionados a sua competência.

A ação do Congresso não pode ir além da discussão e votação dos tributos, entendido que senipre foi serem, nesse campo, apenas essas as sujas obrigações de poder pulitico e legiferante.

O orçainento, segundo os tratadistas modernos, é um plano de govêrno cuja proposta é apresentada ao Conģresso Nacional para que os detentores do mandato popular possam discuti-lo, a fim de ser transformado em lei visando ao bem-estar do povo, objetivo precipuo de tôdas as adminis. trações.

Êste deve, apús o recebimento da proposta do Poder Executivc, sobrepor-se a todos e quaisquer interêsses, a fim de que, em sua elevada área de competência, possa discutir e votar a receita pública dentro da capacidade tributária do povo, nãu o onerancio en demasia para cobrir desresas improdutivas e, "quiçá", adiáveis.

Colaborando, como colaborani, as Ćôrtes de Contas, com as Assembléias Legislativas, para suprir, em tese, a fiscalização que elas nãc poden 
exercer quanto à lei orçamentảria, não devem as mesmas Còrtes fugir à obrigação que thes é imposta de averiguar se as receitas, dentro das esti mativas ficadas, estão sendo berı arrecadadas e recolhidas.

Não poderiam, en cada casc, crımo acontece com a despesa, que é fixada, verificar a exatidão do tributc arrecadado, que é estimado, frente à legislação aplicável. TMas, nas questões aventadas entre a administração e o contribuinte, creio que deveriam opinar, de vez que, afastados das correntes em litigio, teriam oportunidade de, com maior isenção, proferir seu julgamento, devidament? fundamentado nas leis fiscais.

A ação das Côrtes de Contas, no campo da fiscalização, deve ter a maior amplitude, para q:e exerçam real e eficaz vigilância na efetiva e devida aplicação do dinheiro público.

Assim, nãu se pode admitir que, para solucionar contendas entre o Fisco e o contribuinte, sejam criados órgãos colegiados com elementos integrantes da própria Administração interessada e das classes conservadoras, como acontece no Brasil.

Essa organizaçã a ainda aberra de todos os princípios de ordem juridica quando dispõe que da decisão de tais conselhos cabe recurso para o Ministro de Estado que, então, poderá julgar, em instância final, dentro do âmbito administrativo.

Abordəi o problema para definir exatamente que essa questão porieria ser -- ao que tange à divergência entre o Fisco e o contribuinte - o passo inicial do contrôle fiscal da receita ao nascer.

De fato, muito acima das competições, sem quaisquer elos de ordeñ politicc-partidária, procurando sòmente o cumprimento exato das leis fiscais diante das estimativas orçamentárias, as Côrtes de Contas, em proferindo suas decisões, firmariam princípios e diriam do roteiro a ser seguido, estabelecenda jurisprudência que orientaria o próprio contribuinte sôbre seus deveres.

0 assunto em debate tem frofunda repercussão no contrôle fiscal, porque embora a ação das instituiçōes de fiscalização financeira sôt. receita sc evidencie amiúde, jamais se aprofundou nesse campo a fim de executá-la integralmente.

Dirimindo contendas entre o Fisco e o contribuinte, as Côrtes de Contas cogitariam de início, como demonstrei, da fiscalização na fonte, iixando princípios e estabelecendo novas normas se assim julgassem necessário.

De um modo geral, en tôdas as Nações, logo após a decretação da lei orçamentária, os órgãos ad́ministrativos fixam as quotas, segundo a arrecadação do último exercício financeiro, para a cobrança das receitas, de acôrdo com os diversos tributos, nas várias regiões em que se divide o país.

Podem as Côrtes de Contas, fazendo um retrospecto de exercícios anteriores e de justificacöes quie forem apresentadas, verificar desde logo se essas cotas estão próximo da verdade, quanto à estimativa. 
No decorrer do exercício, segundo as comunicações feitas aos Órgãos Superiores de Contrôle, podem êstes constatar a evasão de rendas, se houver, determinando providências que a estanquem, apurando, outrossim, as responsabilidades das autoridades arrecadadoras in loco ou além, se houver conivência .

Parece-me que os levantamentos estatísticos que tenham relação com as rendas públicas, em tôdas as regiōes do país, ao lado de um serviço de contabilidade inecanizado a com pessoal especializado, poderão permitir que as Côrtes de Contas e demais Instituições de Fiscalização Financeira er:frentem o problema adeq̣iadamente, realizando a fiscalização da receita em tôdas is fases da arrecadação. Estas estarão, assim, melhor habilitadas a comparecer às Assembléias Legislativas para afirmar, em os pareceres emitidos quando da apresentação das contas, que a Administração arrecadou acertadamente a receita, segundo os ditames das leis fiscais e a previsão orçamentária ou proclamar, con firmeza, que houve exagêro na estimativa - razão por que o quantum não foi atingido.

Esbocei, em rápidas pinceladas, o planejamento que se parece impor para a fiscalização da receita, eis que: não devem as Côrtes de Contas linitarem-se à verificação do recolhimento aos Bancos ou demais estações arrecadadoras, e, sim, pela própria finalidade de sua missão, verificar se a arrecadação está se processando normalmente em tôdas as suas fases.

Năo poderia, lògicamente, deixar, em debatendo a tese, de me orientar pela situação do problema seguundo se apresenta em meu país, mas tentei firmar principios de ordem geral, que poderão ser aplicados segundo a conveniência e os regimfs estabelecidos em cada Nação.

Os trabalhos apresentados - prenhes de ensinamentos no setor de fiscalização financeira, - partım também do sistema seguido em seus países, esclarecendo o seu funcionamento, para, em seguida, justificar suas pro postas quarito à nova ação fiscal que pretendem seja adotada.

A Itália, em seu trabalho, salienta o imperioso dever de vigilância sôbre a receita, sobretudo nos paises en: que após as duas guerras mundiais, verificou-se uma notável pressão tributária.

Esclarece que a fiscalização da despesa não podendo ser descurada, a sobrecarga das incumbências sôbre as organizações de contrôle as impede de cumprir integralmente as atribuições tocantes à vigilância das receitas públicas.

A unidade e universidade do orçamento provam, entretanto, sem necessidade de maiores indagaçöes, que a fiscalização financeira deve ef_tivar se sôbre o todo, evitando distorçōes máxime na receita - que criem disparidade entre os contribuintes, comprometendo, assim, a gestão orçamentảria.

Duas são as exigências fundamentais que postulam a atuação de uma viggil?ncia eficaz das receitas públicas. A primeira decorrente da necessidade de que o orçamento superior de contrôle tenha sempre visão unitária e de conjunto de todos os fenômenos referentes à gestão do orçamento do 
Estado - encarado sob o duplo àspecto de receita e déspesa - e dessa sua experiência possa valer-se ao se dirigir ao Parlamento analisando para o mesmo as vantagens $e$ os défeitos do sistema vigorante e as modificações que proponha introduzir. A segunda relacionada com a nature finalidade do referido contrôle, que deve assegurar uma garantia efetiva de legalidade de tôda a ação administrativa, em benefício do cidadão contribuinte.

Demonstra, ainda, que a realizaçăo das receitas ocorre através de um complexo processo administrativo, historiando-o em tôda a sua comniementação, e propõe medidas de ordem técnica e contábil que possam melhor solucionar a questão da fiscalização cêsse processo, concluindo que:

“a vigilância sôbre as receitas poderá ter um conteúdo e uma eficácia não inferiores aos que tern o contrôle das despesas".

Essa proposição, que já por mim fôra defendida, por ser umâ resultant? natural das funções atribuidas às Côrtes de Contas, encontra, por seu lado, amparo na tese apresentada pela Bélgica, quando, apreciando a questão, sentencia:

"As atribuições das Côrtes de Contas abrangem tanto o contrô!e das receitas como o das despesas, pois as Constituições não estabeleceram a tal respeito qualquer distinção entre tssas duas formas de operações financeiras, cujo conjunto constitui a conta geral do Estado".

Entendo, entretanto, que as Còrtes de Contas não devem ter qualquer participação nas Assembléias Legislativas quando da elaboração da lei de meios, porquanto só os Podêres emanados do povo, com mandatos diretos quer para lagislar, quei para executar, podem, dentro dos princípios constitucionais, estimar a receita e fixar a despesa.

Deve haver, porén, um órgão intermediário entre o Parlamento e o Governo, que é a Côrte da Contas - ou outros órgãos superiores de contrôle - destinado exclisivamente a fiscalização da execução orçamentária.

Há situações, como acontece no Brasil com referência ao registro "sob reserva» e à recusa de registros de contratos, que são, entretanto, levadas ao conhecimento do Congrasso Nacional, o qual transforma-se então em instância revisora.

Fora dêsses casos, o único liame do Tribunal de Contas com o Congresso Nacional é o parecer sôbre as contas do govêrno, onde os atos e fatos administrativos com reflexo 11 lei orçamentária são apreciados e, com a necessária documentaçăo, encaminhados ao Parlamento, para exame e aprovação.

Nessa oportunidade podem as Côrtes de Contas falar sôbre a reccita arrecadada, frente às cifras alinhadas na lei da meios, dizendo se as estimativas foram exageradas ou, pelu contrário, se a Administração não a arrecadou como devia. 
Assim procede, por exemplo, a Bélgica, cuja Côrte de Contas

"Certifica a exatidão da gestão e envia ao Parlamento suas conclusões a respeito da conta definitiva do orçamento, formulando eventualmentz as observações decorrentez da verificação",

daí resultando que

"As Câmaras Legislativas ficam assim em condições de dar ao Govêrno quitação cie sua gestão, micdiante votação de projeto de lei que encerre definitivamente o orçamento do exercício vencido".

Afirma-se, alhures, que as Côrtes de Contas devem manter ligações com o Parlamento, quando da císcussão e votação da lei de meios.

Creio, porém, que essa não $\dot{\epsilon}$ opinião dominante, porquanto as Côrtes não devem ter interferência $\bullet \mathrm{m}$ atos e fatos que, posteriormente, estarão sujeitos ao seu julgamento.

Consta também da tese da Bélgica que

"Nem a Constituição nem o legislador confiaram às Côrtes de Contas atribuições em matéria de contrôle das finanças municipais".

$\mathrm{E}$, mais adiante, que

"As contas anuais dos municipios, com tôdas as operações de receitas e despesas, são submetidas à aprovação da Comissão Permanente do Conselho Provincial competente, com reserva de recurso eventual para o Rei, que decide sôbre a responsabilidade do Ministro do Interior encarregado da tutela dos municipios".

Esclarecendo que as atribuições confiadas à Côrte de Contas abrangem o conjunto das operações financeiras, com inclusão das receitas do Curgo Belga e da Ruanda-Urundi, declara ainda a Bélgica que a Côrte não possui, entretanto, poder jurisdicional com reterência aos exatores de tais possessões.

$\mathrm{Na}$ França, entretanto, o organismo superior de contrôle examina a legalidade das receitas públicas por ocasião do julgamento das contas do govêrno sujeitas à sua jurisdição e, através do sua Comissão Tributária, vela particularmente pela legalidade das taxas municipais.

O contrôle a posteriori sôbre o recebimento das receitas é jurisdicional e administrativo. Embura tendo como caracteristica comum sua generalidade, diferem notàveimente çuanto ao conteúdo e à sanção êsses tipos de fiscalização.

O primeiro resulta da lei institucional da própria Côrte de Contas que determinou que ela funcionasse como Juiz de Direito comum, julgando todos os responsáveis por dinheiros públicos - enquanto o segundo é um contrôle de regularidade e limitado quanto às receitas, às operações efetuadas pelos responsáveis, resultando de textos constitucionais.

Freqüente e democràticamente as comunicações ao govêrno e ao $\mathrm{Par}$ lamento, em matéria de receitas, pela Côrte de Contas, são incluidàs no noticiário público, ebedecendo à crientação de que a opinião pública deve 
ser informada das irregularidades acaso verificadas no recebimento das ieceitas, e de que o contrôle pela instituição de fiscalização deve constituir para todos a garantia de que a tinissão dos arrecadadores é cumprida com a regularidade e con o cuidado recessários e obrigatórios.

Em Portugal, que declara perfeitamente satisfatória a organização de seus serviços de contrôle, o organismo superior de fiscalização das receitas e o Tribunal de Contas, que julga a posteriori as contas dos responsáveis.

Funciona como Caixa-Geral do Tesouro o Banco de Portugal; no ultramar, entrztanto, o sistema de tesouraria é realizado pelo Banco Nacional Ultramarino ou pelo de Angola.

Estabelece-se, assim, franca distinção quanto à fiscalização financeira das operações efetuadas e!n os territórios ultramarinos porque, como se lê da tese,

"A fiscalização superior da administração financeira é exercida pelo Ministro de Ultramar, por intermédio dos serviços do Ministério".

Na Suiça, o Contrôle Federal das Finanças é o órgão superior da fiscalização da Confederação .

Os Cantôes e os municipios, por fôrça da organização federalista do país, possuem suas próprias instituições de contrôle.

Reconhece a Suiça que:

"O contrôle das receitas é mais difícil de organizar que o das despesas, pois, em numerosos casos, há pouca ou nenhuma possibilidade de exercer contrôle rigido".

Julga que se deverá precer uma organização que permita, com arplitude, impedir qualquer dilapidação de fundos destinados ao Estado, esclarecendo que a organização contábil da Confederação dá ao órgão superior de contrôle a possibilidade de ser exatamente informado da evolução das receitas e despesas.

O problema comum, segundo se depreende das teses apresentadas é o encontro de un sistema que permita a maior penetração no exarrie das receitas desdc a fase inicial, defendendo ponto-de-vista coincidente a Espanha quando diz:

"Feito êste esclarecimento, necessário, sob todos os pontos-de-vista, quanto ao âmbito geral das atribuições ćos Órgãos Superiores de Contrôle, é claro que aquêles que reúnem ambos os aspectos de fiscalização a priori e a posteriori, terão faculdades muito amplas e diretas sôbre o processo arrecadador, ao passo que aquêles que só gozam da fiscalização a posteriori terão sua ação limitada em matéria de arrecadação, pelo fato de atuarem sôbre fatos consumados, com relação a um processo que, como o da arrecadação, terá de ser rápido e dinâmico em sua realização".

Aduz, contudo, aquêle país, que:

"O que anteriormente foi dito não significa que o Tribunal de Contas se encontre totalmente afastado de vigilância do serviço arrecadador". 
Já a Austrália dispõe de um Auditor-Geral, com a Independência de um Juiz de Alta Côrte, não estando stijeito ao titular do Tesouro, nem a qualquer outro Ministro, e corn a responsabilidade sòmente perante o Parlamento.

A Auditoria-Geral, com a sua organização administrativa, exerce a necessária fiscalização sôbre atos e fatos referentes à receita e à despesa, determinando providências de ordera contábil e fiscal e levando o seu exame à exposição que the é feita pelo Ministro do Tesouro, com referência às conta: do exercício, que, com o seı parecer, são encaminhadas ao Parlamento.

A Constituição do Japão prevê, também, uma Auditoria que tem como a mais importante de suas funções a fiscalização do encerramento das contas de receita e despesa do Estado.

Quanto à fiscalização da receita, examina a Auditoria se o montante dos impostcs está de acôrdo con a legislação, se foram ou não empregados segundo os preceitos legais, e se houve excesso ou deficiência no recolhimento. Nesse último caso; a Auditoria comunicará o fato diretamente ao Ministério da Fazenda, para a correção da irregularidade.

A China Nacionalista, aproximando-se dessa organização, dispõe de um corpo de auditores, acreditados junto ao Tesouro Nacional, com a fin lidade de verificar os atos referentes à gestão orçamentária.

Propõe ao III Congresso, como medida de real interêsse, que os tribunais de contas recomendem a fixação da receita dentro da real capacidade tributária do povo.

Na Iugoslávia, além dos órgãcs administrativos e dos bancos, encarregados de zelar pela realização das receitas do orçamento e fundos, existe um órgão especial - a Inspetoria Financeira - encarregado de exercer inspeção sôbre tôda a gestão.

Os bancos dispõem de um serviço de investigação social. que poderá coletar dados sôbre ocorrências econômicas e proporcionar outras inciicações à fiscalização financeira.

Na Nova Zelândia, há o Departamento de Contas, que deve realizar os exames que considerar necessários aos livros e contas dos funcionários contábeis e de quaisque: outras pessoas ligadas à cobrança, recehimento, custódia ou dispêndio de fundos ou bens públicos.

Tratando dos casos de falta de exação, aquêle país esclarece:

"Se um funcionário contábil cu outra pessoa, voluntária ou negliçentemente, deixar de arrecadar ou dar conta de qualquer quantia, o Departamento de Contas poderá forçar o responsável a repô-la".

$\mathrm{Na}$ Áustria. o contróle do Tribunal de Contas se exerce sôbre todos os atos financeiramente importantes praticados pelo govêrno central, pelas províncias federais, pelas municipalidades , pelas instituições independentes que sejam administradas por órgão de govêrno central, das provincias federais e das municipalidades ou por sua ordem. 
Além disso, sua ação se estende a tôda a administração de emprêsas come: ciais e industriais de propriedade do govêrno central, pelas províncias federais ou por uma municipalidade e às emprêsas financeiramente mantidas por una dessas entidades.

Opina que as Côrtes de Contas devem ser encarregadas do contrôle das receitas agindo como procuradores do fisco, salvaguardando os interêsses do Estado.

A Tailândia, cujas receitas são arrecadadas pelo Departamento da Receita, Departamento do Impôsto de Consumo e Departamento da Alfândega, há três órgãos controladores das finanças públicas locais, enquanto o exame das contas de todos os órgãos governamentais incumbe ao Conselho de Contrôle Financeiro, com ampla ação fiscalizadora e com competência para exigir que os tuncionários responsáveis por qualquer irrę̧ularidade reponham quaisquer qquantias cuja prestação de contas não seja satisfatória.

A Turquia, confere ao seu 'Tribunal de Contas atribuiçñes de duas categnrias: controlar o sistena de contis do Estado, submetendo, por mei, de relatóric, a Grande Assembléia Nacional, as propostas de rodificações ou melhoramentos que entender necessárias, e controlar a devida aplicação da Lei de Contabilidade do Estado aos levantamentos de contas, a arrecadaçio e as operaçoes anuais dos cobraciores.

Esclarece que o iesuitiulc anual de contrôle da aplicação das receitas do Estado is submetido ao Parlanento juntamente com a declaração de aprovação geral que é obrigado a apresentar, em relação ao orçamento tarefa para a qual está devida e perfeitamente equipado.

O Dr. Victor do Amaral Freire, Assistente Técnico - Chefe do Tribunal de Contas de São Paulo, diz, em seu trabalho, que a fiscalização da receita:

"embora constitua atribuição do maiur relêvo, tem sido releģadá a plano sectindário pelas investigações de contrôle financeiro".

Ressalta o valor da receita na vida administrativa do pais, encarecendo - fato de que é através da arrecadação que os governos realizanı a sua politica financeira.

De seu longo e acurado estudo, demonstrando, com proficiência, que a vigilância, pelas instituições de contrôle, deve ter a mesma extensão nn dominio das receitas quanto no das despesas, resultou a proposta, que assim se resume:

"As instituições de contrôle devem exigir contas dos responsáve:s pela receita, de maneira a alcançar não só os que tenham recebido arrecadações. como também àqueles que, por omissão, negligência, desídia ou má-fé possam contribuii para o não recebimento de dinheiros ou valores públicos".

Estabelecendo a Lei Maior, no Brasil, o regime federativo, fácil é concluir que as afirmações feitas se referem às receitas da União - são con- 
troladas pelo Órgão Superior, porque os Estados e Municipios estão subordinados, respectivannente, à fiscalização dos órgãos estaduais ou municipais.

Procurei realçar, no desempenho do mandato que me foi conferido, os métodos e as proposta's de fiscalização sôbre a receita, a fim de que os debates se possam processar em campo de maior amplitude.

Os Senhores Congressistas já leram as teses em debates, e, assim, êste relatório tem efeito, meramente, de reativação da lembrança dos problemas nelas focalizados.

Integrando o Corpo Deliherativo de um órgão superior de contrôle das finanças públicas, terei, talvez, avançado, sem o pretender, proposições que devessem influir sôbre o mérito cio assunto, cujo julgamento é de competência do Plenário do Congresso.

$\mathrm{S}$ ₹ tal aconteceu, apresso-me a apresentar minhas escusas, esclarecendo, outrossim, que, em relatando a matéria, não me poderia deixar de ater ao processo da fiscalização financeira em meu país, e, empolgado pelo assunto, referir-me até às suas raizes históricas. Estou certo de que serei compreendido e perdoado.

Cabe-me, ainda, como Relator-Geral da Tese, apresentar as conclusões finais, para a'provaçăo da Comissão Técnica e posterior encaminhamento à Comissão Geral do Congresso, após o pronunciamento dos Senhores Congressistas, ja inscritos, que, por certo, ilustrarão os debates, permitindo, assim, coletar maiores ensinamentos para solucionar o problema, ora equacionado. 